Notes and miscellanea

\section{Effects of exposure to slate dust in North Wales}

Despite the absence of adequate data on dust exposure, the paper by Glover et al (37:152-62) does appear to show a dose-response relation in that occupations in the quarries which one might presume to have had high dust exposure have a greater prevalence of category 2 pneumoconiosis, and more which is of earlier onset.

The authors, however, recognise the confusion caused by the high prevalence of tubercular lesions, particularly in the older workers. Until fairly recent times, the real problem in North Wales was the pla gwyn - the white scourge.The average annual crude death rate per million from tuberculosis between 1930 and 1936 was more than 2000, the highest in Britain. Even in 1951 it was 1110 compared with 310 for England and Wales as a whole. This must be seen in the context of the appalling social conditions prevailing in North Wales up to and even after the second world war. Housing conditions in Gwyrfai in 1938 were similar to those we now associate with the less developed parts of the Third World. ${ }^{1}$ Given that open tuberculosis was endemic in the community, Jarman ${ }^{2}$ points out that its prevalence among quarrymen was considerably higher than among men in the community at large, and he, among others, suggested that there might be an occupational factor to account for this. Glover et al express the same view in rather a different way but both imply that there is a cause and effect relation between dust exposure, pneumoconiosis, and the prevalence of tuberculosis. This problem is the subject of unpublished work by Swedish investigators, but until this is available we should pay due regard to other possible factors in the excess of tuberculosis in slate quarrymen over the already high prevalence of tuberculosis in the community in which they lived.

Among these factors were, for example, the use of barrack accommodation that persisted into the years of the second world war, although on a rapidly diminishing scale. In these barracks men slept five or six to a room, sometimes two or three in one bed in the worst conditions. Many men travelled to work by train, and it was well known that there were clean and dirty carriages-the latter to be avoided if at all possible on account of the amount of dried sputum contaminating the environment. The more skilled categories of quarrymen took their meals together in the cabarnau. Elementary hygiene rules seem to have been enforced in these mess rooms, at least during the last years of the slate quarrying industry ( $\mathrm{R}$ Keen, personal communication), but they clearly allowed opportunity for further spread of the disease.

These social and public health factors necessitate some caution in drawing conclusions about the effect of dust among the North Welsh slate quarrymen. In this context it is interesting to note the reaction to Jarman's report ${ }^{2}$ to the Welsh Office in 1957 on the prevalence of tuberculosis in the North Wales slate quarrying areas. He showed the excess of cases of tuberculosis among the quarrymen compared with men in the community at large and with that disclosed by the Rhondda Fach survey carried out in the early 1950s. The North Wales Slate Quarries Association (the owners' organisation) expressed their pleasure at the indications in this report that people working in the quarries would be less likely to contract tuberculosis than those employed outside. ${ }^{34}$ The kindest interpretation one can put on such a statement is that they grossly misunderstood Jarman's report!

Jarman also commented on the reluctance of the quarrymen and others to attend for radiological examination. This reluctance led to the continuation of a pool of old chronic infectious cases in the community. This aspect attracted considerable press comment, 56 and it seemed to be generally agreed that the wellestablished fear of what had been historically an incurable disease lay beneath the difficulty in persuading people to attend for diagnosis and treatment. Glover noted that many men with pneumoconiosis in North Wales never applied for compensation. One might speculate that one of the reasons for this is the same historic fear of the possible dread results of a chest radiograph. Twentyfour per cent of the study population failed to attend for radiography in Jarman's survey. Glover et al must be congratulated on a $94 \%$ response. Perhaps the old nightmare is at last disappearing.

A JONES

Employment Medical Advisory Service, Wales

\section{References}

${ }^{1}$ Ministry of Health. Report of the Committee of Inquiry into the Antituberculosis Service in Wales \& Monmouthshire. London: HMSO, 1939.

2 Jarman JF, Glyn Jones J, Phillips JH, Seingry HE. Radiological surveys of working quarrymen and quarrying communities in Caernarvonshire. Br J Ind Med 1957; 14:95-104. (This includes the material in Jarman's report to the Welsh Office in March 1957.) 
3 Liverpool Daily Post 1957 Mar 19.

${ }^{4}$ Liverpool Daily Post 1957 Mar 22.

${ }^{5}$ Western Mail 1957 Mar 18.

- Flintshire Observer 1957 Mar 22.

\section{Dr Oldham replies:}

Jones's letter gives most useful information about the extraordinarily high prevalence of tuberculosis in North Wales and the social conditions that could have contributed to it, but he is misinterpreting us in suggesting that we attributed this in part to dust exposure.

We showed that, if all radiological large shadows in men with compensatable degrees of simple pneumoconiosis (category 2 or more) were called complicated pneumoconiosis then the remaining large shadows occurred no more frequently, age for age, than in men with no occupational dust exposure. Thus the prevalence of tuberculosis without advanced simple pneumoconiosis was certainly not a consequence of dust exposure.

As for men with advanced simple pneumoconiosis, the frequency of large shadows among them appeared to be less than in South Wales coalworkers, so that even if complicated pneumoconiosis were always tubercular in origin (and this has not been shown) again no excess attributable to dust exposure was discovered.

\section{The August 1980 issue}

\section{THE AUGUST 1980 ISSUE CONTAINS THE FOLLOWING PAPERS}

Angiosarcoma of the liver: annual occurrence and aetiology in Great Britain P J BAXTER, P P ANTHONY, $R$ N M MACSWEEN, AND P J SCHEUER

Adenocarcinoma of the nose and paranasal sinuses in shoemakers and woodworkers in the province of Florence, Italy (1963-77) F CECCHI, E BUIATTI, D KRIEBEL, L NASTASI, AND M SANTUCCI

A 20-year follow-up of men aged 55-64 including coal-miners and foundry workers in Staveley, Derbyshire A L COCHRANE AND F MOORE

A 20-year follow-up of a population sample (aged 25-34) including coal-miners and foundry workers in Staveley, Derbyshire A L COCHRANE AND F MOORE

An investigation of the acute behavioural effects of styrene on factory workers NICOLA CHERRY, H A WALDRON, G G WELLS, R T WILKINSON, H K WILSON, AND SALLY JONES

A comparative study on the neurotoxicity of n-pentane, n-hexane, and n-heptane in the rat $Y$ TAKEUCHI, Y ONO, N HISANAGA, J KITOH, AND Y SUGIURA

Occupational type bronchial provocation tests: testing with soluble antigens by inhalation $M \quad G$ HARRIES, P S BURGE, AND I M O'BRIEN
Changes in lung function after exposure to vanadium compounds in fuel oil ash R E M LEES

Radiological findings as predictors of mortality in Quebec asbestos workers F D K LIDDELL AND J C MCDONALD

Effect of smoking on attack rates of pulmonary and pleural lesions related to exposure to asbestos dust G H G MCMILLAN, R J PETHYBRIDGE, AND G SHEERS

Clearance of asbestos bodies from the lung: a personal view $\mathrm{K} J$ ARUL AND P F HOLT

Cadium-induced osteomalacia J D BLAINEY, R G ADAMS, D B BREWER, AND T C HARVEY

Application of mathematical modelling for assessing the biological half-times of chromium and nickel in field studies A TOSSAVAINEN, $M$ NURMINEN, $P$ MUTANEN, AND S TOLA

High affinity of lead for fetal haemoglobin $\mathrm{C} \mathrm{N}$ ONG AND W R LEE

48-hour ambulatory electrocardiography in dynamite workers and controls C HOGSTEDT, B SÖDERHOLM, AND L BODIN

Fever induced by fluorine-containing lubricant on stainless steel tubes B ÅKESSON, B HÖGSTEDT, AND S SKERFVING

Information section 